\title{
Soft Tissue Fibrosarcoma
}

National Cancer Institute

\section{Source}

National Cancer Institute. Soft Tissue Fibrosarcoma. NCI Thesaurus. Code C6605.

A usually agg ressive malignant neoplasm arising from the soft tissue. It is characterized by the presence of spindle-shaped fibroblasts and collagenous stroma formation in a herring bone growth pattern. 